\title{
Key pillars of the facile cooperation between environmental and cultural education in Poland
}

\author{
Tomasz Pasierbek \\ Babiogórski National Park, P1 34-223 Zawoja 1403 \& University College of Tourism and Ecology, Zamkowa 1 \\ P1 34-200 Sucha Beskidzka, Poland \\ E-mail address: tpasierbek@,bgpn.pl
}

\begin{abstract}
National parks are created in order to protect the unique features of the most valuable natural areas of Poland. These protected areas as ideal "research laboratories" can function as almost model examples of ecosystems of which discovering is important not only for science but also can be used in practice. They are also essential destinations for large groups of tourists searching for other experiences than those offered in crowded resorts. Additionally, they are also a fantastic "didactic help" and it's hard to overestimate their role in education. Many contents regarding biology but also geography are perfectly suitable to be realized in terrain. However, environmental education is not only about presenting the complexity of processes occurring in nature (including those within living things) or a science explaining how to recognize different species. Legislation regarding local history and tourism might be treated as a tool allowing to introduce contents that are virtually absent in the core curriculum to the didactic process through linking of the objectives of local history with the objectives of the particular lectures/classes. One of the crucial objectives that are geared toward the conduct of environmental education is the creation of the feeling of responsibility for the environment that surrounds us.
\end{abstract}

Keywords - national parks, community participation, environmental education, cultural education, Poland

\section{INTRODUCTION}

Contemporary education presumes a practical approach to teaching. For a long time, now it is not sufficient to simply memorize dry definitions - that is both inefficient and meaningless. Society expects of a young man that is leaving the walls of a high school or a university not only knowledge but first and foremost specific abilities and skills (Greenwood, 2012). It should be said plainly, however, that those can be nurtured through the education led in a practical way which allows the student to discover something autonomously basing on the theoretical knowledge received before (Blumenfeld et.al 1991). This kind of quality change in the education system should be particularly distinct regarding environmental education and science which should be, as a principle, taught possibly in the most practical way. Frequent access to the school laboratory will however not be enough. Many contents regarding biology but also geography are perfectly suitable to be realized in terrain. It is true that this kind of fieldwork might be conducted in the vicinity of the school, in the school garden, public park or by the river located near the school but it is worth to plan a longer trip from time to time to give children and youth an opportunity to commune with nature that has been not affected in a significant way by humanity. Perfect places to conduct this type of lectures are areas that are covered by various forms of environment protection - particularly gems of Polish nature constituted by national parks. It should be remembered that environmental education is not only about presenting the complexity of processes occurring in nature (including those within living things) or a science explaining how to recognize different species. At the same time, it is a method to create an appropriate attitude of respect and loving toward the nature that surrounds us and to realize that we also are only a part of a bigger picture. It is not possible to reach this particular objective without relating to the term of "little homeland". 
People have, since the beginning of time, lived not only close to nature but also with nature, as part of nature. That is why while discussing one's own identity it should be clearly pointed out that heritage that we received after our ancestors does cover both culture and nature. They both constitute a solid foundation regarding who we are and if we cut off any of these elements, we would make ourselves to be like a tree without roots.

\section{"SAGE'S GLASS AND EYE"1 - ENVIRONMENTAL EDUCATION IN PRACTICE}

National parks are created in order to protect the unique features of the most valuable natural areas of Poland. They constitute true shrines of nature, nature that on their area is simply astonishing, attractive and encouraging to discover its secrets. These areas definitely deserve to be protected which does not mean that they are completely excluded from the circle of interest of man (Mekkonen, 2015). Protected areas as ideal "research laboratories" can function as almost model examples of ecosystems of which discovering is important not only for science but also can be used in practice. They are also an essential destination for a large group of tourists searching for other experiences than those offered in crowded resorts. Additionally, they are also a fantastic "didactic help" and it's hard to overestimate their role in education. All this makes it so national parks are visited by many tourists each year. It is very much the same with Babia Góra - every year it becomes a destination for trips for more than 100000 tourists. Not only do they want to admire great sights, but they are also usually keen on discovering new information about the Queen of Beskids. Most of the organized groups visiting Babiogórski National Park are constituted by groups of children and youth for whom their visit in the park is a part of the didactic process. Employees of the Babiogórski National Park are often visiting near schools and preschools to conduct educational activities about the natural features of Babia Góra. This makes peculiar ecological education centers out of National Parks and they play a key role on a map of public and non-public educational facilities in the region.

Why should Park even address environmental education? It's not in the least the vision of administration of Park which would be dependent on who currently manages the protected areas. National Park in Poland is established pursuant to the regulation of Council of Ministers defining among others the area, borders and protective buffer area ("otulina") of the Park. It covers under its protection an area of more than 1000 ha with exceptional natural, scientific, social, cultural and educational features, where the entirety of environment and landscape is protected. The main objective of every national park is - as according to the legislation about environment preservation - preserving biologic diversity, resources, creations and elements of inanimate nature, restoring the correct state of resources and components of the environment and recreating plant habitats, animal habitats and fungi habitats $^{2}$. Thus, defined objectives explain one essential matter - in the national park human activity is permitted even in the field of reconstruction of nature elements directed at restoring them to their original state.

The abovementioned Legislation about environment preservation defines not only objectives but also tasks of the national parks, particularly emphasizing:

a) Conducting protective activities in the ecosystems of the national park that are conducted in order to reach statutory objectives of the national park;

b) Making the area of the park available per the rules defined in the protection plan or protection tasks and in the regulations of the director of the park;

c) Conducting activities related to environmental education ${ }^{3}$.

Even though the first task is quite obvious and does not require any additional comments, two next tasks require a little bit broader outlook on the matters of nature protection. National parks are created on the areas that are the most valuable areas from a natural point of view and as such, they do deserve special treatment and that is an undeniable fact. A key matter, in this case, is limiting the anthropo-pressure, including also the physical presence of people (Lundmark et. al. 2010). We cannot forget however that national parks are also - even though it might sound pompous - not only the property of the whole nation but even whole international society. Another issue that is important for the existence of all protected areas is connected to that fact. It is impossible to protect a particular area without the support of the community, especially on the local level (Némethy, 2019). In the era of information transformation into fast-moving and valuable product nature protection must be also efficiently "sold". Going back to the national park tasks defined above making the park available for the tourism, sport, and recreational purposes and conducting educational activities in the field of environment protection should be directed toward the creation of a positive image of protected areas. Thanks to them social reception of the national parks is heading toward acceptation and understanding and not toward rejection caused by prohibitions and limitations.

"Conducting activities related to the environmental education", as defined by the abovementioned legislation, in itself presumes the necessity to go into the field. It is possible to conduct stationary lectures in the venues of a museum or exhibition sort and also in classrooms of schools cooperating with the parks, however, this will definitely not achieve full utilization of the potential of protected areas. While possessing such a genius "didactic help", constituted by Babia Góra, locking oneself inside walls of any facility is, to say it subtly, non-sense. This awareness is not only alive in

${ }^{2}$ Legislation from 16 April, 2004, about nature preservation (Dz. U. 2004 Nr 92 poz. 880), art. 8.2

\footnotetext{
${ }^{3}$ Ibid., art. $8 \mathrm{~b}$
} 
minds of employees of the Park that organize lectures but also in minds of teachers who together with their classes frequently visit Babiogórski National Park. As a result of that from one year to another the number of groups of children and youth using the wide offer of fieldwork activities conducted at the foot of the Babia Góra increases.

At this moment it would be great to consider what are the legal bases - are there even any - regarding the tourism and education availability of the protected areas for children and youth. Subsequent changes implemented in the education system definitely do not help in finding your way among the complicated rules applying during the organization of trips to the national parks. Still, at the very beginning of the Education Law legislation ("Prawo oświatowe") currently in force, among the tasks of this particular system we can find at least three which realization of almost directly encourage children and youth to go for field trips. Above mentioned legislation states - education system ensures in particular:

- Popularizing knowledge about rules of balanced development and creating attitudes encouraging its implementation on the local, national and global scale among children and youth.

Ensuring conditions to develop the interests and abilities of students through the organization of extra-curricular classes and the creation of social activities and the ability to spend free time.

Popularizing knowledge about safety among children and youth and creating appropriate attitudes regarding threats and unusual situations (art. 1 of Education Law legislation) ${ }^{4}$.

Each of these tasks requires knowledge from a teacher that is significantly exceeding obligatory minimum but also presumes a non-standard approach to the presented contents. It's difficult to expect students to understand the rules of balanced development if there is no possibility to show how they fare in practice. There can be no discussion about providing conditions for the individual development of student's interests if teachers only work with the students inside the school walls. One can theorize about matters related to the safety but how much better it is to discuss this kind of matters during mountain trip where participation requires from student to show particular behaviors and to adhere to prevailing rules.

A separate issue that should be tackled is the question of how does - in the light of regulations of the Education Law legislation - using services of educators employed in the educational teams of national or landscape parks during the school trips look like. Luckily, the legislator did not presume

${ }^{4}$ Legislation from 14 December, 2016. Education Law (Dz.U. 2017 poz. 59), art. 1

5 Ibid., art. 3

${ }^{6}$ Ibid., art. 109

${ }^{7}$ Legislation from 16 April 2004, about environment preservation (Dz. U. 2004 Nr 92 poz. 880), art. 103 the necessity to lead those kinds of field trips exclusively by teachers. Article third of the Education Law legislation clearly states that the education system is supported by the non-governmental organizations, including scouting organizations and also legal persons that conduct statutory activities in the field of education ${ }^{5}$. What is more, even though in the catalogue of basic forms of didactic and educational activities that are included in the abovementioned legislation there is no reference to field trips and fieldwork, the legislator has allowed schools to have significant freedom in this matter. It is stated that school can conduct other activities/lectures than those listed in the summary above ${ }^{6}$. However, do national parks fulfill statutory rules applying to the units that are supporting the education system? The answer can be found in the Legislation about environment preservation that is defining the rules of creation and functioning of all elements of the environment preservation system in Poland. Abovementioned notations from the article $8 \mathrm{~b}$ of the said legislation that enforces, among others, the task of conducting environmental education by the national park seems to be fulfilling the necessity to conduct a statutory educational activity that is required of institutions supporting educational system and that is expected by the legislator. By analyzing further notations of the legislation about environment preservation a notation that is additionally enhancing this particular reasoning can be found. Article 103 of the legislation, describing the tasks of the National Park Service, states clearly that one of those tasks is to make the area of the park available for the purposes of science, education, recreation, tourism, and sports ${ }^{7}$.

\section{"TO THE MOUNTAINS, TO THE MOUNTAINS MY DEAR

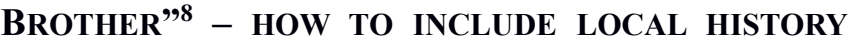 STUDIES AND TOURISM UNDER THE FRAMES OF EDUCATION}

In the educational matters, the legislator has not left much to pure chance. Legally regulated are not only matters related to the very education system (abovementioned Education Law legislation) or the issue of afterschool relaxation (legislation from 11 September 2015 regarding the change of the legislation about education and the legislation about National Criminal Register) ${ }^{9}$. The matter that remains open is the question where in the education system one should place tourism and local history studies that are realized on the school level and how important from the didactic process point of view is this particular topic. It is quite obvious that the lecture "Local history" is not going to be found in the hourly schedule of a typical school. It should also be remembered that subsequent reforms in education removed

\footnotetext{
${ }^{8}$ Wincenty Pol: Pieśń o ziemi naszej (Song of our land)

${ }^{9}$ Legislation from 11 September, 2015, regarding the change of the legislation about education and the legislation about National Criminal Register (Dz. U. 2015 poz.1629)
} 
from the system terms that were a perfect fit for the term of "Local history" which were understood as a set of contents and skills that possessed essential cognitive and didactic significance and which realization of can be conducted through the conduct of lectures or separate classes ${ }^{10}$. The currently binding Regulation of the Minister of National Education from 27 August 2012, regarding the core curriculum for the preschool education and general education in the particular types of schools does not include different paths of education ${ }^{11}$. Without a doubt, this constitutes a hindrance in the planning of any additional extra educational activities that would be related to local history studies or tourism. This state of affairs means that teachers who would like to introduce contents related to local history require the ability to properly fit appropriate subject matters in regard to the currently prevailing core curriculum or to create their own original programmes that would include the extracurricular topic. If any determined pedagogue would like to tackle this particular topic, they should refer to the Regulation of the Minister of National Education and Sport from 8 November 2001, regarding the conditions and methods of organizing public preschools, schools, and local history and tourism facilities $^{12}$. This particular regulation empowers public educational institutions to organize different distinct types of local history and tourism-related classes for their students. What is more, similar as with sensu lato education, in case of local history studies and tourism a possibility to cooperate with associations and other subjects that conduct activities related to local history and tourism has been envisaged. In this case, once more, a possibility appeared to use protected areas, especially national parks that as per the legislation possess a task to make their areas available for the tourism purposes (among others).

Legislation regarding local history and tourism might be treated as a tool allowing to introduce contents that are virtually absent in the core curriculum to the didactic process through linking of the objectives of local history with the objectives of the particular lectures/classes. It is not difficult to highlight a parallel with the "classic classes" that are present in the hourly schedule of a school, if among the objectives of organizing local history and tourism studies at the school level are listed as:

1) discovering the country, its environment, tradition, cultural and historical monuments,

2) discovering the culture and languages of other countries,

3) enhancing knowledge from the different areas of social, economic and cultural life

4) supporting family and school in the education and didactic process,

${ }^{10}$ Regulation of the Minister of National Education from 15 February, 1999, regarding the core curriculum for general education (Dz.U. 1999 nr 14 poz. 129) - legal act repealed

${ }^{11}$ Regulation of the Minister of National Education from 27 August, 2012, regarding the core curriculum for the preschool education and general education in the particular types of schools (Dz.U. 2012 r. poz. 977)
5) popularizing the rules of environment protection and the ability to use the natural resources among children and youth, 6) enhancing physical fitness,

7) enhancing the health of children and youth from the areas that are ecologically vulnerable,

8) popularizing forms of active recreation,

9) counteracting social pathology,

10) learning the rules of safe conduct in different situations ${ }^{13}$.

Above mentioned regulation thus links local history contents with the classes such as nature, biology, geography, history, knowledge about society, Polish language or security awareness. By defining the allowed forms of local history and tourism classes, especially rules that are applying when organizing trips, this regulation should constitute the essential supporting point for the task of planning the didactic process on the particular levels of education.

\section{"TOGETHER WITH OTHER, IN TEAM, IN ORDER TO..."14 - COOPERATION FOR THE EDUCATION}

Deliberations regarding the legal possibilities of using national parks in the didactic process lead to the obvious conclusion that even though it is definitely not easy because of organizational and often financial reasons (especially if the school is far from the seat of the park) it is definitely worth to involve national parks in the process (Clifton, 1981; Coyle and Senser, 2015). Most importantly students are benefitting from having the opportunity to discover the contents that are already in the core curriculum from a completely new perspective. It is not, however, possible to conduct ecologic education - and most definitely it cannot be done effectively - in isolation and separation from the cultural heritage. For centuries ancestors of contemporary citizens of the vicinity of Babia Góra have lived surrounded by the raw, mountain nature. It was that nature that determined their sleep-wake rhythm and year rhythm, ensured their food and shelters, and eventually it was that nature that inspired them and that inspiration can be found in the folk art.

Aiming to create a sense of respect for the world that surrounds a young person we cannot simply focus on only one of the protected aspects. One cannot exclusively accentuate natural values and forget while doing so about cultural heritage, likewise, one cannot only talk about the cultural values and omit completely the natural heritage. The awareness regarding that fact constitutes a basis for the longterm cooperation between Babiogórski National Park with seat in Zawoja and local cultural institutions. Even though those institutions concern themselves with other matters -

\footnotetext{
${ }^{12}$ Regulation of the Minister of National Education and Sport from 8 November, 2001, regarding the conditions and methods of organizing public preschools, schools and local history and tourism facilities (Dz.U. $2001 \mathrm{nr} 135$ poz. 1516)

${ }^{13}$ Ibid., $\$ 2$

14 Jerzy Wasowski: Jeżeli kochać (If you love)
} 
from the standpoint of assumed effects of the didactic process one should acknowledge the synergy existing between their activities.

Cooperation between the Babiogórski National Park and institutions related to the culture or protection of the heritage of local communities concern a few practical aspects:

- cooperation in the creation of plans and educations projects, - consultations both on the level of the executive staff and on the level of teams that are directly in charge of education are conducted on an ongoing basis. This is essential especially when planning activities in a perspective of the next year but also on the stage of the creation of projects designed to apply for the external assets,

- participation in the events organized by the partner including workshops, training, conferences, vernissages, author meetings, open-air events and so on,

- joint organization of temporary exhibitions.

Because of the insufficient spatial conditions, Babiogórski National Park enjoys the hospitality of (among others) Orawski Ethnographic Park or Municipal Centre of Culture ("Zamek") in Sucha Beskidzka during their temporary exhibitions. The theme of these exhibitions is always related to both natural and cultural values.

\section{SUMMARY}

One of the crucial objectives that are geared toward the conduct of environmental education is the creation of the feeling of responsibility for the environment that surrounds us. Appropriate behavior toward nature and respecting its values might stem from (for example) fear regarding the possible administrative penalty for breaking the law or from the current fads and trends. If these will be the only rationale standing behind particular decisions one cannot expect that those will be in any way permanent. Fashion is something that comes and goes, it always changes, and fear has never been a good foundation to build any appropriate behaviors. It does not work in relation to the adults and even more so it will not work in case of children attending schools. Meanwhile the phrase "what youth is used to, age remembers..." applies even in this case - appropriate attitudes should be learned at an early age. Obviously, it should be done skillfully, using contemporary achievements of education. First and foremost, however, young people should be made aware that the nature of their closest vicinity is a particular element of their own identity. It is not possible without showing them the strong ties between nature and culture on a local level. At the foot of the Queen of Beskidy, this particular bond is particularly visible, that is why it is so important to cooperate in the field of environment protection - cultural heritage protection. Only by working together one can hope that future generations of citizens of the vicinity of Babia Gora will look at it with the same love as their ancestors did.

\section{REFERENCES}

\section{Articles and other research publications}

Blumenfeld, P. C., Soloway, E., Marx, R. W. Krajcik, J.S., Guzdial, M. \& Palincsar, A. (1991): Motivating ProjectBased Learning: Sustaining the Doing, Supporting the Learning. Educational Psychologist, Volume 26, 1991 - Issue 3-4, pp. 369-398.

DOI: $\underline{10.1080 / 00461520.1991 .9653139}$

Clifton, N. (1981): School use of national parks for outdoor education: a case study of Arthur's Pass National Park. Lincoln University, MSc thesis.

https://researcharchive.lincoln.ac.nz/handle/10182/2302

Coyle, K.J. and Senser, K. (2015): An Educational Resource Guide for the "Every Kid in a Park" Program. National Wildlife Federation, October 20, 2015.

https://www.nwf.org/ /media/PDFs/Kids-and-Nature/AnEducational-Resource-for-the-Every-Kid-in-a-ParkProgram.ashx

Greenwood, D. J. (2012): Doing and learning action research in the neo-liberal world of contemporary higher education. Action Research, Volume: 10 issue: 2, page(s): 115-132 DOI: $\underline{10.1177 / 1476750312443573}$

Lundmark, L. J. T., Fredman, P., and Sandell, K. (2010): National parks and protected areas and the role for employment in tourism and forest sectors: a Swedish case. Ecology and Society 15(1): 19. [online]

URL: $\underline{\text { http://www.ecologyandsociety.org/vol15/iss1/art19/ }}$

Mekkonen, M. A. (2015): Environmental role of National Parks. Journal of Sustainable Development; Vol. 9, No. 1; 2016. ISSN 1913-9063 E-ISSN 1913-9071; Published by Canadian Center of Science and Education.

DOI: $10.5539 /$ jsd.v9n1p1

Némethy, S. (2019): The Balaton Ecomuseum - Touristic Product and Landscape Management in One System. In English with English and Polish abstract; chapter in monography: Parki Narodowe $i$ Otoczenie Społeczno Gospodarcze. Skazani na Dialog (National Parks and the Socio-economic Environment. Condemned to Dialogue) pp. 175 - 203. Wyższa Szkoła Turystyki $i$ Ekologii w Suchej Beskidzkiej, ISBN 978-83-947044-1-4

\section{Legal text references in footnotes}

1. Legislation from 14 December, 2016, Education Law (Dz.U. 2017 poz. 59)

2. Legislation from 11 September, 2015, regarding the change of the legislation about education and the legislation about National Criminal Register (Dz. U. 2015 poz.1629) 
3. Regulation of the Minister of National Education from 15 February, 1999, regarding the core curriculum for general education (Dz.U. 1999 nr 14 poz. 129) - legal act repealed

4. Regulation of the Minister of National Education from 27 August, 2012, regarding the core curriculum for the preschool education and general education in the particular types of schools (Dz.U. 2012 r. poz. 977)

5. Legislation from 16 April, 2004, about nature preservation (Dz. U. 2004 Nr 92 poz. 880)
6. Regulation of the Minister of National Education from 23 December, 2012, regarding the core curriculum for the preschool education and general education in the particular types of school (Dz. U 2009 r. Nr 4 poz. 17)

7. Regulation of the Minister of National Education and Sport from 8 November, 2001, regarding the conditions and methods of organizing public preschools, schools and local history and tourism facilities (Dz.U. $2001 \mathrm{nr} 135$ poz. 1516) 